\title{
Pilsicainide Intoxication in a Patient With Dehydration
}

\author{
Shin-ichiro Ozeki, MD; Toshinori Utsunomiya, MD*; \\ Shuzo Matsuo, MD*; Katsusuke Yano, MD**
}

\begin{abstract}
An 81-year-old woman developed pilsicainide intoxication associated with dehydration. The patient had been taking pilsicainide $(100 \mathrm{mg} /$ day) for 1 year because of paroxysmal atrial fibrillation. Her renal function was within normal limits. One week before admission, she was suffering from pneumonia, and had appetite loss, fever, and severe fatigue. Physical examination revealed dehydration. The electrocardiogram (ECG) on admission showed atrioventricular dissociation, idioventricular rhythm with marked QRS widening and QTc prolongation. The plasma concentration of pilsicainide on admission was markedly elevated at $6.2 \mu \mathrm{g} / \mathrm{ml}$, approximately 6 times the therapeutic range $(0.25-1.0 \mu \mathrm{g} / \mathrm{ml})$. Continuous saline infusion was initiated for the treatment of dehydration, which progressively improved. As a result, sinus rhythm was recovered $2 \mathrm{~h}$ after admission, and the QRS and JT intervals gradually normalized. This is an interesting case because the proarrhythmia of pilsicainide was induced by dehydration. (Jpn Circ J 1999; 63: 219-222)
\end{abstract}

Key Words: Arrhythmia; Dehydration; Pilsicainide

$\mathbf{P}$ ilsicainide is a class Ic antiarryhthmic drug which has been confirmed to be effective in the management of clinical arrhythmia 1,2 Recently, adverse effects of the class Ic antiarryhthmic drugs, such as flecainide and propafenone, have been reported? Overdoses have been known to induce various arrhythmias such as idioventricular rhythm, torsade de pointes and ventricular tachycardia. Pilsicainide has been shown to increase PQ interval, QRS width and QTc, and the percentage prolongations of the PQ interval were well correlated with the plasma pilsicainide levels. It has been reported that an excess dose of pilsicainide taken during an attempted suicide induced incessant ventricular tachycardia? Pilsicainide is rapidly absorbed from the gastrointestinal tract and most of that is excreted from the kidney. Its halftime is short, indicating that its accumulation does not occur easily in patients with normal renal function. We report here the first known case of pilsicainide intoxication precipitated by dehydration in an aged patient who took the usual daily dosage for about 1 year.

\section{Case Report}

A 81-year-old woman visited hospital with the chief complaints of severe fatigue and fever. She had been taking pilsicainide ( $100 \mathrm{mg} /$ day $)$ and amlodipine $(5 \mathrm{mg} /$ day $)$ for 12 months for paroxysmal atrial fibrillation and hypertension. She has also begun to take furosemide $(20 \mathrm{mg} /$ day $)$ for further blood pressure control approximately 6 months prior (December 1997). In the follow-up period, there were no abnormal findings on electrocardiogram (ECG) or laboratory examinations including electrolytes, urea nitrogen (BUN) and creatinine (Cr). The plasma pilsicainide

(Received August 20, 1998; revised manuscript received November 19, 1998; accepted December 3, 1998)

Department of Cardiology, Saga National Hospital, *Division of Cardiology, Department of Internal Medicine, Saga Medical School, Saga and **Third Department of Internal Medicine, Nagasaki University School of Medicine, Nagasaki, Japan

Mailing address: Shin-ichiro Ozeki, MD, Department of Cardiology, Saga National Hospital, 1-20-1 Hinode, Saga 849-0923, Japan concentration was $0.25 \mu \mathrm{g} / \mathrm{ml} 12 \mathrm{~h}$ after takin a $50 \mathrm{mg}$ tablet orally.

Seven days before admission, she had a fever of up to $38^{\circ} \mathrm{C}$. Over the next 7 days, fatigue and appetite loss gradually developed. In April 1998, she took her usual $50 \mathrm{mg}$ tablet of pilsicainide and $5 \mathrm{mg}$ tablet of amlodipine at 09.00 $\mathrm{h}$, after which she was brought to hospital by ambulance at $11.00 \mathrm{~h}$ because of progressive fatigue.

Physical examination on admission revealed the following findings: height and body weight were $147 \mathrm{~cm}$ and 38 $\mathrm{kg}$, respectively. She was alert and a hand tremor was noticed. Body temperature was $38.8^{\circ} \mathrm{C}$, heart rate was regular at 70 beats/min with normal heart sounds, respiratory rate $22 / \mathrm{min}$, and blood pressure (BP) $82 / 48 \mathrm{mmHg}$. Moist rales were audible in the right precordial area. In addition, her tongue and skin were quite dry. Urinalysis showed hypersthenuria (specifie gravity 1.030) and positive ketone bodies. Laboratory examination revealed a white blood cell count (WBC) of $12,300 / \mathrm{mm}^{3}$, C-reactive protein (CRP) of $18.4 \mathrm{mg} / \mathrm{dl}, \mathrm{BUN}$ of $40.7 \mathrm{mg} / \mathrm{dl}$, and $\mathrm{Cr}$ of

Table 1 Laboratory Findings During the Clinical Course

\begin{tabular}{|c|c|c|c|}
\hline & December 23, 1997 & April 3, 1998 & April 4, 1998 \\
\hline$W B C\left(/ \mathrm{mm}^{3}\right)$ & 6,100 & 12,700 & 8,840 \\
\hline$R B C(\times 104 \mu l)$ & 38 & 423 & 385 \\
\hline$H b(g / d l)$ & 10.7 & 11.6 & 10.4 \\
\hline $\operatorname{Hct}(\%)$ & 34.9 & 36.9 & 33.8 \\
\hline Plt $(\times 104$ Al) & 24.1 & 28.2 & 28.5 \\
\hline $\mathrm{Na}(\mathrm{mmol} / \mathrm{L})$ & 142 & 130 & 138 \\
\hline$K(\mathrm{mmol} / \mathrm{L})$ & 3.9 & 4.5 & 3.2 \\
\hline $\mathrm{Cl}(\mathrm{mmol} / \mathrm{L})$ & 104 & 91 & 103 \\
\hline $\mathrm{Ca}(\mathrm{mg} / \mathrm{dl})$ & 8.4 & 8.2 & \\
\hline$P(m g / d l)$ & 3.5 & 3.5 & \\
\hline Total protein $(g / d l)$ & 7.5 & 7.2 & 5.6 \\
\hline Albumin $(g / d l)$ & 3.5 & 3.5 & 2.7 \\
\hline$B U N(\mathrm{mg} / \mathrm{dl})$ & 15.7 & 40.7 & 12.0 \\
\hline $\mathrm{Cr}(\mathrm{mg} / \mathrm{dl})$ & 0.6 & 1.2 & 0.5 \\
\hline$C R P(m g / d l)$ & 0.1 & 18.4 & 13.1 \\
\hline
\end{tabular}

WBC, white blood cells; RBC, red blood cells; Hb, hemoglobin; Hct, hematocrit; Plt, platelets; BUN, blood urea nitroges; $C r$, creatinine; $C R P$, C-reactive protein. 
(A)

(B)

(C)

(D)

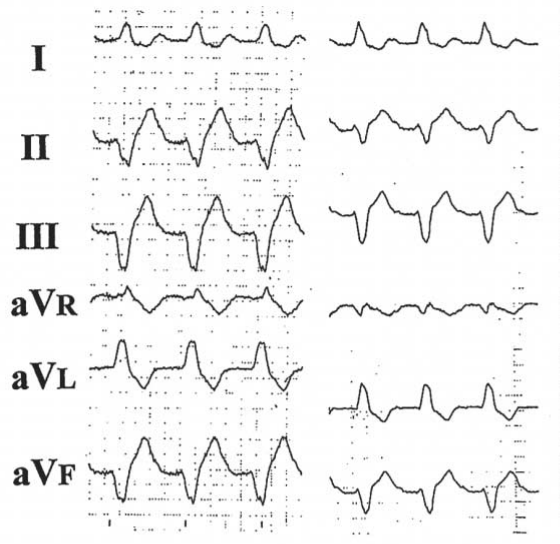

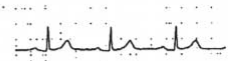

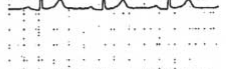

hll li
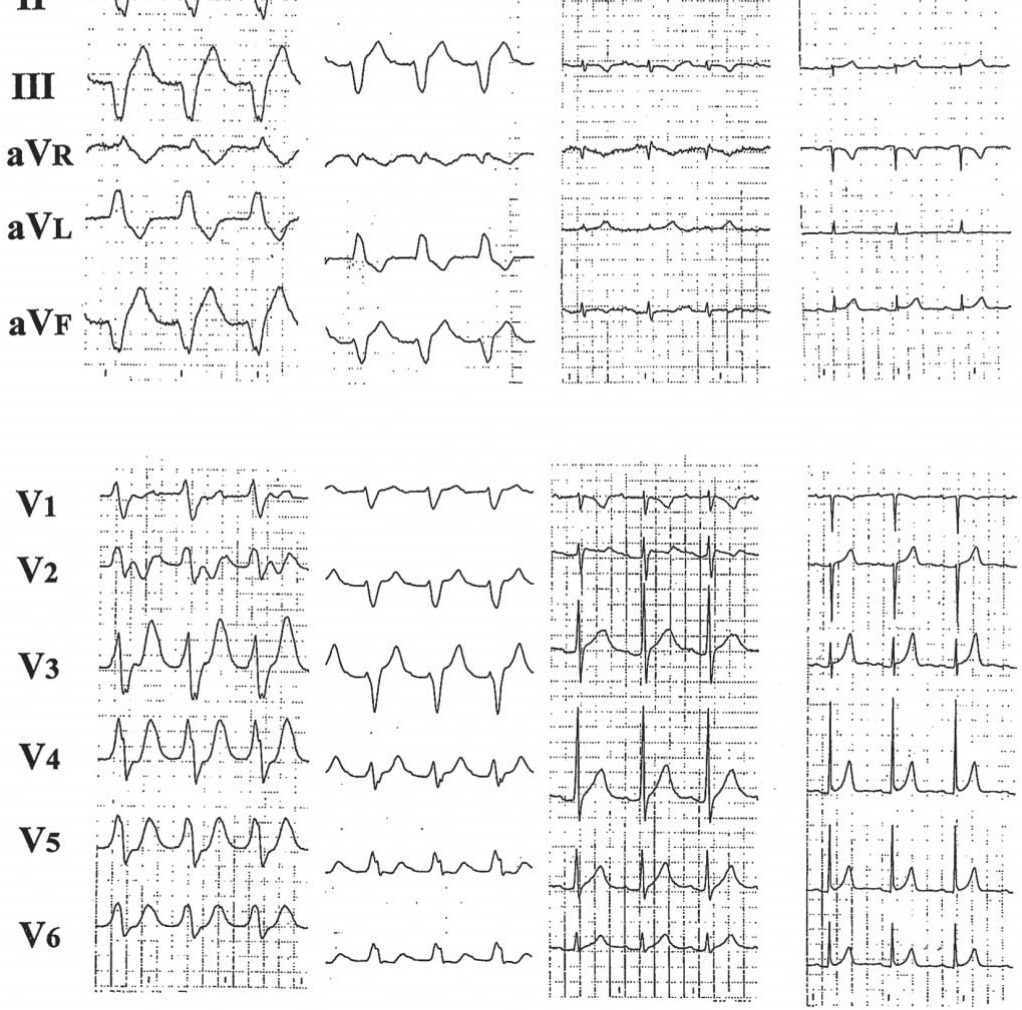
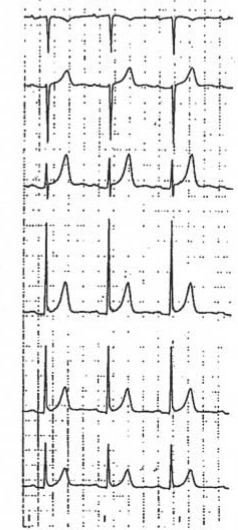

Fig 1. Electrocardiograms recorded after admission. (A) $11.00 \mathrm{~h}$. (B) $13.00 \mathrm{~h}$. (C) $16.00 \mathrm{~h}$ on April 3, 1998 and (D) $09.00 \mathrm{~h}$ on April 4, 1998. (A) Idioventricular rhythm with marked QRS and QTc prolongation (QRS: 0.28s, QT: 0.74 s). (B) Firstdegree AV block with QRS and QT prolongation (PQ: $0.28 \mathrm{~s}$, QRS: $0.24 \mathrm{~s}$, QTc: $0.52 \mathrm{~s}$ ). (C) Firstdegree AV block with iRBBB (PQ: $0.24 \mathrm{~s}$, QRS: $0.12 \mathrm{~s}$, QTc: $0.48 \mathrm{~s}$ ). (D) Normal sinus rhythm (PQ: $0.10 \mathrm{~s}$, QRS: 0.10s, QTc: 0.42s).

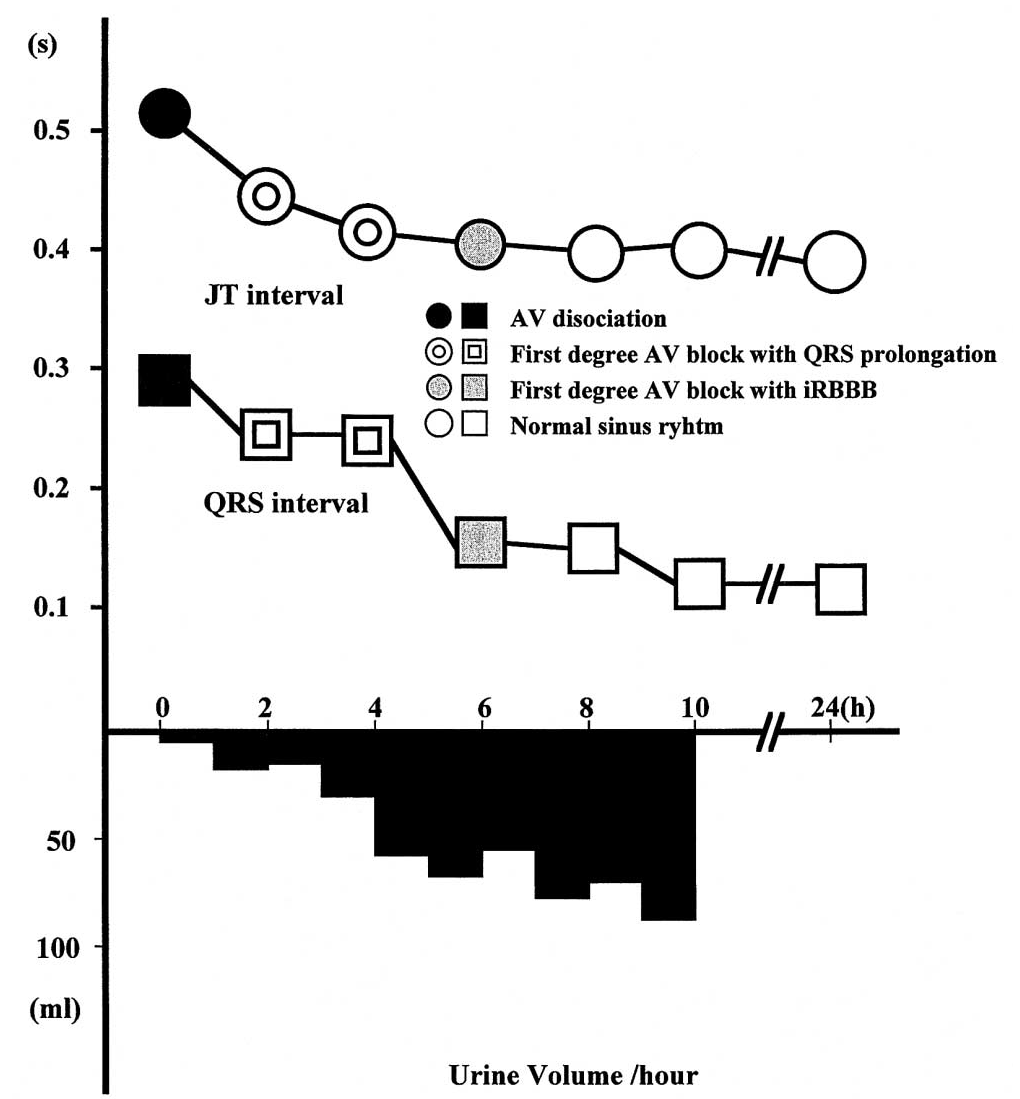

Fig 2. Changes of QRS and JT interval (upper axis) and urine volume (lower axis) after admission. Continuous saline infusion gradually increased urine volume. Simultaneously, the prolongation of the QRS and JT intervals normalized. 
$1.7 \mathrm{mg} / \mathrm{dl}$ (Table 1). Arterial blood gas analysis showed mild hypoxia and metabolic acidosis $\left(\mathrm{PO}_{2} 63.5 \mathrm{mmHg}\right.$, $\mathrm{PCO}_{2} 33.2 \mathrm{mmHg}$, pH 7.347, $\left.\mathrm{HCO}_{3}-18.2 \mathrm{mmol} / \mathrm{L}\right)$. An ECG revealed idioventricular rhythm with marked prolongation of the QRS and JT intervals (QRS: $0.28 \mathrm{~s}$, JT: $0.52 \mathrm{~s}$ ) and atrioventricular (AV) dissociation (Fig 1A). A chest radiograph showed mild cardiomegaly (cardiothoracic ratio $52 \%$ ), and an infiltration shadow in the right lower lobe. Echocardiography on admission showed that the wall motion and size of the heart were almost normal (AoD 30 $\mathrm{mm}$, LAD $35 \mathrm{~mm}$, IVS $11 \mathrm{~mm}$, PW $10 \mathrm{~mm}$, EDD $46 \mathrm{~mm}$, ESD $30 \mathrm{~mm}$, EF $72 \%$, FS $35 \%$ ). From these findings, we suspected pilsicainide intoxication associated with dehydration, and we measured the plasma concentration of pilsicainide. It was markedly elevated at $6.2 \mu \mathrm{g} / \mathrm{ml}$, approximately 6 times the normal range.

The patient's clinical course is shown in Fig 2. After admission, continuous saline infusion $(100 \mathrm{ml} / \mathrm{h})$ was immediately initiated. Two hours later, sinus rhythm was recovered, but the PR interval was significantly prolonged $(0.28 \mathrm{~s})$ and the wide QRS and JT intervals still continued (Fig 1B). Fig 2 shows the changes in the JT interval, QRS interval and urine volume. In the first $4 \mathrm{~h}$, her urine volume was approximately $5-30 \mathrm{ml} / \mathrm{h}$ and her systolic BP was 90-110 mmHg. Five hours after admission, however, her urine volume was increased $(50-100 \mathrm{ml} / \mathrm{h})$ and systolic BP was elevated to $130 \mathrm{mmHg}$. The QRS and JT intervals also gradually shortened. At $6 \mathrm{~h}$ after admission, ECG showed an incomplete right bundle branch block (iRBBB) pattern, and the PQ, QRS and JT intervals were $0.24 \mathrm{~s}, 0.12 \mathrm{~s}$ and $0.40 \mathrm{~s}$, respectively (Fig $1 \mathrm{C}$ ). On the next day, the $\mathrm{iRBBB}$ had disappeared and the PQ interval had normalized (Fig 1D). Laboratory data including BUN and $\mathrm{Cr}$ were improved (Table 1), and her creatinine clearance was 58 $\mathrm{ml} / \mathrm{min}$.

Pilsicainide was discontinued on admission. In addition, piperacillin ( $2 \mathrm{~g} /$ day) for pneumonia was continued for 2 weeks. As a result, the infiltrating shadow in the right lower lobe almost disappeared.

\section{Discussion}

Pilsicainide is an antiarrhythmic agent with class Ic properties ${ }^{1,2}$ Proarrhythmia is one of the most important adverse effects of this drug. Cellular electrophysiologic studies have revealed that this drug exhibits a selective sodium channel-blocking action with very slow kinetics, and clinical electrophysiologic studies have demonstrated that pilsicainide lengthens not only the $\mathrm{AH}$ and $\mathrm{HV}$ intervals but also the sinoatrial conduction time, and results in prolongation of the duration of $\mathrm{PQ}, \mathrm{QRS}$ and QTc4. Pilsicainide has a negative inotropic effects, such as BP and stroke volume reduction? On admission of the present patient, we observed AV dissociation and idioventricular rhythm with marked QRS and QTc prolongation, which were coincident with blood pressure reduction. Although the QTc interval was markedly prolonged, torsade de pointes did not occur in her clinical course, which may be related to QT dispersion. Increased dispersion of the QT interval has been suggested as an indicator of increased risk of ventricular tachycardia in patients with idiopathic long QT syndrome? In the present patient, the QT dispersion measured on ECG was $52 \mathrm{~ms}$ on admission, and was in the normal range?

Of interest, pilsicainide intoxication appeared 12 months after the initiation of treatment in this patient, and the plasma concentration of pilsicainide was markedly elevated at approximately 6 times the normal range. Why was the plasma concentration of pilsicainide increased so markedly despite the usual daily dosage? We speculated the reason was as follows. Orally administered pilsicainide is absorbed rapidly and $95 \%$ is excreted in the urine mostly unchanged. Peak pilsicainide levels are attained within 1-2 $\mathrm{h}$ and its halftime is $3-5 \mathrm{~h}$, which leads us to consider that its accumulation does not usually occur in patients with normal renal function. Takabatake et al have demonstrated that pilsicainide's half-time of elimination was $3.4 \mathrm{~h}$ in normal subjects and was prolonged to $23.7 \mathrm{~h}$ in severe renal failure? The present patient's renal function was within normal limits, and the plasma pilsicainide concentration was within the normal range in December 1997. On admission, the decrease in water intake and appetite was continued for at least 7 days. Moreover, the administration of furosemide might have accelerated dehydration. Her creatinine clearance was estimated according to S-Nielsen et al ${ }^{10}$ to be approximately $25 \mathrm{ml} / \mathrm{min}$ on admission. This impaired renal function was induced by dehydration, and may have caused prolongation of the half-time of pilsicainide and resulted in an elevated plasma concentration. Actually, the continuous saline infusion rapidly improved not only the decreased urine volume and $\mathrm{Cr}$ but also the QRS and JT intervals, and her creatinine clearance on the next day was $58 \mathrm{ml} / \mathrm{min}$.

Furthermore, the patient's age may be an another factor in the increased plasma concentration of pilsicainide. Creatinine clearance usually decreases with age by 1 $\mathrm{ml} / \mathrm{min}$ per year after 40 years of age, and reduction of water intake may occur in the elderly because of a reduced sensation of thirst.11 This case shows that aged patients can easily lapse into dehydration and subsequently cause a transient decrease of creatinine clearance, and this provoked a marked elevation of the plasma pilsicainide concentration in the present patient. Intensive care must, therefore, be taken to avoid high concentrations of pilsicainide developing, and close blood level monitoring and dosage adjustment are particularly required in aged patients.

\section{References}

1. Ino T, Atarashi H, Hayakawa H: Electrophysiologic and hemodynamic effect of SUN 1165, a new antiarrhythmic agent. In: Toyama J, Hondeghem LM, editors. Current topics in antiarrhythmic agents. Tokyo: Excerpta Medica, 1989: 219-229

2. Terazawa T, Suzuki M, Goto T, Kato R, Hayashi H, Ito A, et al: Suppressive effect of SUN 1165 on supraventricular tachycardia. Am Heart J 1991; 121: $1437-1444$

3. Koppel C, Oberdisse U, Heinnemeyer G: Clinical course and outcome on class IC antiarrhythmic overdose. J Toxicol 1990; 28: $433-444$

4. Ino T, Atarashi H, Kuruma A, Onodera T, Saitoh H, Hayakawa H: Electrophysiologic and hemodynamic effects of a single oral dose of pilsicainide hydrochloride, a new class $1 \mathrm{c}$ antiarrhythmic agent. $J$ Cardiovasc Pharmacol 1998; 31: 157-164

5. Kanda H, Nakamura M, Yaguchi Y, Mochizuki Y, Yamamoto M, Yasuda $\mathrm{H}$ : A case of survival from incessant ventricular tachycardia caused by an excess dose of pilsicainide hydrochloride in Japanese. Resp Circ 1997; 45: 197-200

6. Nakashima M, Kanamaru M, Uematsu T, Ohnuma N, Hayashi T, Oh-uchi M, et al: Phase 1 study of SUN 1165, a novel antiarrhythmic agent. No. 1: single dose study. J Clin Ther Med 1989; 5: 661-678

7. Sakanashi M, Noguchi K, Matsuzaki T, Ojiri Y, Nakasone J, Itomine $\mathrm{T}$, et al: Effect of pilsicainide on systemic hemodynamics and cardiac function of anesthetized dogs. Cardioscience 1993; 4: $241-250$ 
8. Statters DJ, Malik M, Ward DE, Camm AJ: QT dispersion: problems of methodology and clinical significance. $J$ Cardiovasc Electrophysiol 1994; 5: 672-685

9. Takabatake T, Ohta H, Yamamoto Y, Ishida Y, Hara H, Ushiogi Y, et al: Pharmacokinetics of SUN 1165, a new antiarrhythmic agent, in renal dysfunction. Eur J Clin Pharmacol 1991; 40: 411-414
10. S-Nielsen K, Hansen JM, Kampmann J, Kristensen M: Rapid evaluation of creatinine clearance. Lancet 1971; 1: 1133-1134

11. Andreucci VE, Russo D, Cianciaruso B, Andreucci M: Some sodium, potassium and water changes in the elderly and their treatment. Nephrol Dial Transplant 1996; 11(Suppl 9): 9-17 